\title{
Phytochemical and molecular analyses of some Coleus cultivars cultivated in Egypt
}

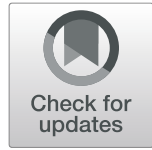

\author{
Rashad M. Shoaib ${ }^{1 *}$ D, Sami I. Ali ${ }^{2}$, Sami A. Metwally ${ }^{3}$, Mohamed M. Ibrahim ${ }^{1}$ and Kamal A. Aboud
}

\begin{abstract}
Background: Coleus (family Lamiaceae) is a popular garden ornamental plant known for its bright-colored foliage. The effective role of different plant growth regulators have been widely reported in plant cultivars (Singh A and Prasad SM Int. J. Sci. Eng. Appl. Sci. 2 (1): 1-10, (2016)). Kinetin has received great interest due to its richness in bioactive phytochemicals including polyphenolic compounds with its antioxidant activity. Molecular markers have been very helpful in enhancing our understanding of genome structure and function. In our study, we investigated the effect of three treatments of kinetin on the phytochemical contents of five Coleus cultivars and molecular characterization by ISSR markers.

Results: The studied cultivars of Coleus revealed adequate amounts of pigments chlorophyll a (Cha), chlorophyll b (Chb), and total carotenoids (Carot) as well as phytochemical ingredients including total carbohydrates (Carb), total phenolic (TP), total flavonoids (TF), and total tannins (TT). Finger paint cultivar $\left(C_{5}\right)$ revealed the highest values $(0.266,10.853,11.648$, and $6.722 \mathrm{mg} / \mathrm{g})$ of Carb, TP, and T, respectively, while the highest contents (11.814 and $11.648 \mathrm{mg} / \mathrm{g}$ ) of TF were identified in Beckwhites gem species $\left(C_{2}\right)$ and finger paint cultivar $\left(C_{5}\right)$, respectively. Intersimple sequence repeat (ISSR) marker analysis was performed on the samples with 5 primer pairs. These bands were identified as 21 polymorphic and 18 monomorphic ones with $53.8 \%$ polymorphism. Ten unique bands were identified in the resulted ISSR profile.

Conclusion: These results suggested that the effect of kinetin treatments stimulates secondary metabolites production. Also, ISSR marker is helpful for possible distinguishing, identifying, characterizing, and selection processing of Coleus cultivars.
\end{abstract}

Keywords: Coleus, Cytokinins, Kinetin, Phytochemical, ISSR markers

\section{Introduction}

Coleus (family; Lamiaceae) is an ornamental plant which can beautify the environment. It is a vegetative pot plant (Singh and Prasad 2016). Cytokinin revealed direct impact on different parameters of photosynthesis in plants including chlorophyll and synthesis and breakdown of chloroplast compounds, enzyme activities, and electron transfer (Pospisilova et al. 2005). The stimulatory effects of cytokinins on biosynthesis process of major secondary metabolite in Coleus aromaticus Benth (L), flavonoid

\footnotetext{
* Correspondence: rashadshuaib@gmail.com

${ }^{1}$ Genetics and Cytology Department, National Research Centre, Dokki, GizaP.O. 12622Egypt

Full list of author information is available at the end of the article
}

biosynthesis in Scutellaria alpina shoot cultures, and cucurbitacin content in Citrullus colocynthis were reported (Grzegorczyk-Karolak et al. 2017). Kinetin, one of the most essential members of cytokinins, is promising in such regard (Zhang et al. 2017). The polyphenolic compounds, one of the most important categories of plant secondary metabolites, especially flavonoids, phenolics, and tannins, showed different biological activities including antioxidant and antiviral activities (Mohamed et al. 2016). The chemical contents of bioactive compounds in plants is strongly dependent on the plant species with its different varieties and thanks to the reported stimulatory effects of cytokinins on biosynthesis process of bioactive secondary metabolite in different plants. 
Molecular markers have been widely used in studies on germplasm resource identification, phylogeny of species, plant taxonomy, evolution, and genetic diversity Abdel Khalik and Osman (2017). ISSRs are regions in the genome flanked by microsatellite sequences. Polymerase chain reaction (PCR) amplification of these regions using a single primer yields multiple amplification products that can be used as a dominant multilocus marker system for the study of genetic variation in various organisms ( $\mathrm{Ng}$ and $\mathrm{Tan} 2015$ ). ISSR markers are easy to use, cheap, and less demanding compared to other dominant markers, making it an ideal genetic marker for beginners and for plant species whose genetic information is lacking ( $\mathrm{Li}$ et al. 2007). ISSR markers have been extensively used to determine genetic diversity among Coleus sp. (Tripathi 2013), within seven species of the genus Plectranthus (Lamiaceae) from Saudi Arabia (Abdel Khalik and Osman 2017), in Radix astragali (Liu et al. 2016), within pecan plants (Jia et al. 2011), between $A$. capillaris (Shafie et al. 2011), among Angelica species (Mei et al. 2015), and in wild Portuguese orchardgrass (Costa 2016). The first exploration of the genetic and chemical diversity of natural populations to identify elite chemotype(s) variability of forskolin content and existing molecular diversity in the wild population of C. forskohlii was by Srivastava et al. (2017). This encouraged us to evaluate the effect of kinetin treatments on the five cultivars of Coleus with molecular characterization by ISSR markers.

\section{Materials and methods}

A pot experiment was performed during the two successive seasons, 2016 and 2017, at the green house of the National Research Centre, Dokki, Cairo, Egypt, to study the effect of kinetin upon growth and chemical constituents of the five cultivars of Coleus blunei. For cultivation, the five cultivar's seedlings, uniform in size and shape (2-3 leaves), were kindly supplied from the ornamental and aromatic research station, Ministry of Agriculture. The five cultivars were Color Clouds spicy $\left(C_{1}\right)$, Beckwhites gem $\left(C_{2}\right)$, Solar red $\left(C_{3}\right)$, Colorblaze alligtore tears $\left(C_{4}\right)$, and finger paint $\left(\mathrm{C}_{5}\right)$ (Fig. 1). The kinetin treatments and agriculture practices were determined according to Sami et al. (2018).

\section{Extraction of plant materials}

Fine air-dried powder $(1 \mathrm{~g})$ of each Coleus sample was extracted with $10 \mathrm{ml}$ of methanol under shaking at room temperature on an orbital shaker (Heidolph Unimax 2010) for $48 \mathrm{~h}$. Each extract was filtered using filter paper (Whatman No.1). The final volume of each filtrate was adjusted to $10 \mathrm{ml}$ with methanol. A representative plant sample from the three replicates from each treatment was taken after 180 days from planting in which chemical constituents were determined as follows.

\section{Phytochemical analysis}

Photosynthetic pigments Cha, Chb, and Carot according to Saric et al. (1967) and total soluble carbohydrate percentage by using colorimetric methods which were described by Smith et al. (1956) were used in the phytochemical analysis. Total phenolic content was determined in methanol extracts by Folin-Ciocalteu reagent according to Singleton and Rossi (1965). The aluminum chloride method was used for the determination of total flavonoid (TF) content in methanol extracts (Zhishen et al. 1999). Total tannin (TT) of each

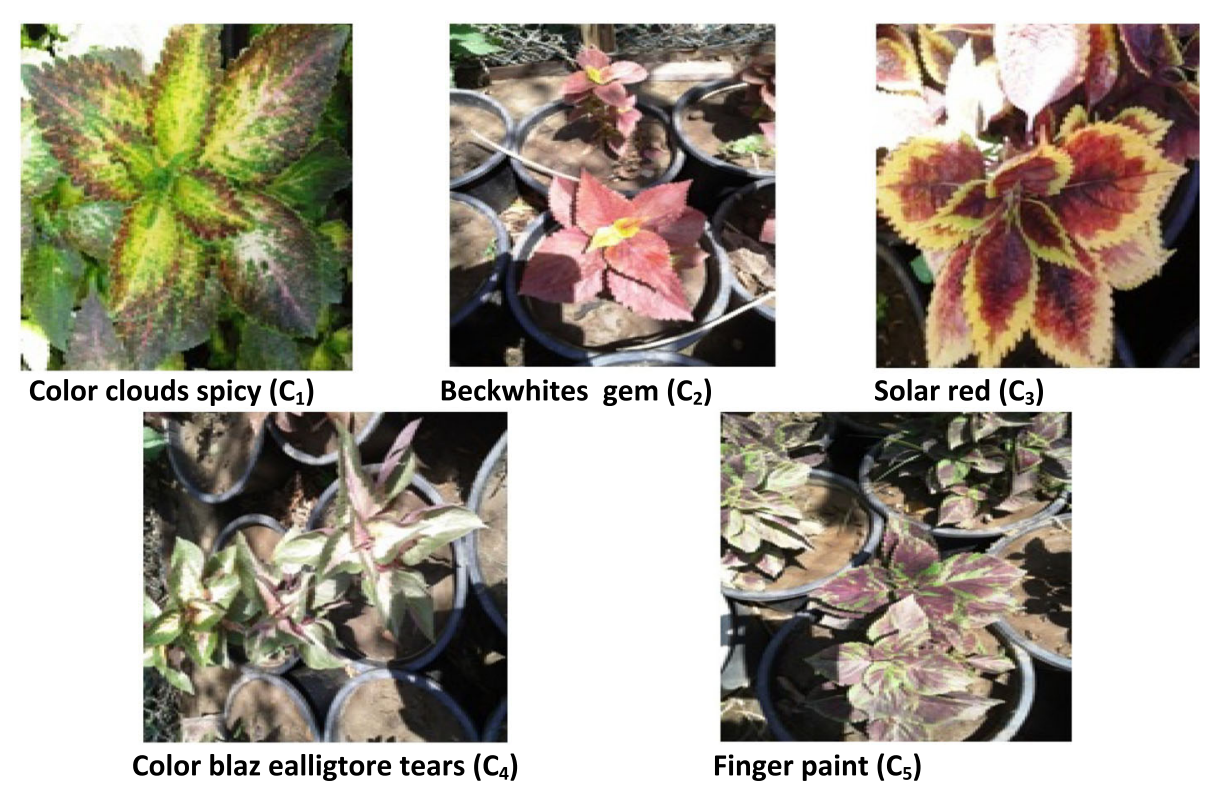

Fig. 1 Morphological description of the five Coleus cultivars 
extract was measured using the Folin-Ciocalteu reagent assay (Polshettiwar et al. 2007).

\section{Molecular analysis DNA isolation}

Leaves of the five seedlings of Coleus were collected and soaked in liquid nitrogen for DNA extraction, and the DNA was extracted by cetyltrimethylammonium bromide (CTAB) method (Doyle and Doyle 1990).

\section{Polymerase chain reaction (PCR) procedure}

ISSR analyses were performed as described by Adawy et al. (2004) and Hussein et al. (2006). Five ISSR primers were used shown in Table 4. The PCR was performed according to methods described by Shoaib et al. (2016) and Sami et al. (2018).

\section{The PCR conditions}

The PCR amplification was performed in a $25-\mu \mathrm{l}$ reaction volume containing the following: $200 \mu \mathrm{l}$ of dNTPs $(2.5$ $\mathrm{mM}), 1.5 \mu \mathrm{l}$ of $\mathrm{Mg} \mathrm{Cl}_{2}$ (25 mM), $2.5 \mu \mathrm{l}$ of $10 \mathrm{x}$ buffer, $2.0 \mu \mathrm{l}$ of primer $(2.5 \mu \mathrm{M}), 2.0 \mu \mathrm{l}$ of template DNA $(50 \mathrm{ng} / \mu \mathrm{l})$, $0.3 \mu \mathrm{l}$ of Taq polymerase $(5 \mathrm{U} / \mu \mathrm{l})$, and $14.7 \mu \mathrm{l}$ of sterile $\mathrm{dd}$ $\mathrm{H}_{2} \mathrm{O}$. The reaction mixtures were overlaid with a drop of light mineral oil per sample. Amplification was carried out in Perkin Elmer Gene Amp PCR System 2400. The reaction was subjected to one cycle at $95{ }^{\circ} \mathrm{C}$ for $5 \mathrm{~min}$, followed by 35 cycles at $94{ }^{\circ} \mathrm{C}$ for $30 \mathrm{~s}, 55^{\circ} \mathrm{C}$ for $30 \mathrm{~s}$, and $72{ }^{\circ} \mathrm{C}$ for $30 \mathrm{~s}$, then a final cycle of $72{ }^{\circ} \mathrm{C}$ for $5 \mathrm{~min}$. PCR products were run at $100 \mathrm{~V}$ for $1 \mathrm{~h}$ on $1.2 \%$ agarose gels which mixed with $\mathrm{lx}$ TBE buffer, and ethidium bromide was added to the melted gel after the temperature became $55{ }^{\circ} \mathrm{C}$. Gels were photographed and scanned with Bio-Rad video densitometer model 620, at a wavelength of 577 .

\section{Data analysis}

The obtained resulted were subjected to statistical analysis of variance according to the method described by Snedecor and Cochran (1980), and the combined analysis of the two seasons was calculated according to the method of Steel and Torrie (1980). The similarity matrices of ISSR markers were done using Gel works ID advanced software UVPEngland Program. The relationships among cultivars as revealed by dendrograms were done using SPSS for Windows (version 16) program. DICE computer package was used to calculate the pairwise difference matrix and plot the phenogram among cultivars (Yang and Quiros 1993).

\section{Results}

Effect of kinetin treatments on the phytochemical contents of Coleus cultivars

Chlorophyll pigments $\mathrm{Cha}, \mathrm{Chb}$, and Carot ranged from $1.209,3.654$, and $3.733 \mathrm{mg} / \mathrm{g}$ in cultivar $\mathrm{C}_{1}$ to $2.914 \mathrm{mg} / \mathrm{g}$ in cultivar $\mathrm{C}_{2}$ and 12.013 and $10.594 \mathrm{mg} / \mathrm{g}$ in $\mathrm{C}_{5}$, respectively (Table 1 ). Cultivar $\mathrm{C}_{5}$ revealed the highest values $(0.266,10.853,11.648$, and $6.722 \mathrm{mg} / \mathrm{g}$ ) of Carb, $\mathrm{TP}$, and TT, respectively, as compared to the other cultivars (Table 1). Compared to the other cultivars, the highest contents $(11.814$ and $11.648 \mathrm{mg} / \mathrm{g})$ of TF were identified in cultivar $\left(C_{2}\right)$ and cultivar $C_{5}$, respectively (Table 1 ).

Different treatments of kinetin showed significant effects $(P \leq 0.05)$ on the contents of pigments (Cha, Chb, and Carot), Carb, TP, TF, and TT. One hundred fifty parts per million (K3) treatment gave rise to the highest values $(2.221,9.851$, and $9.225 \mathrm{mg} / \mathrm{g}$ ) of Cha, Chb, and Carot, respectively (Table 2). The highest content of Carb $(0.255 \mathrm{mg} / \mathrm{g})$ resulted in $100 \mathrm{ppm}$ (K2) treatment. The highest contents $(8.729$ and $5.259 \mathrm{mg} / \mathrm{g})$ of TP and TT was associated with $0 \mathrm{ppm}$ (K1) treatment, respectively, while the highest content $(9.674 \mathrm{mg} / \mathrm{g})$ of TF resulted in 200 ppm treatment (Table 2).

The results of Table 3 displayed significant effects $(P \leq$ 0.05 ) of different treatments of kinetin on the different cultivars of Coleus. K1 and K3 of kinetin gave the highest contents $(4.083$ and $3.940 \mathrm{mg} / \mathrm{g}$ ) of Cha with cultivar $\mathrm{C}_{2}$, respectively, followed by $3.143 \mathrm{mg} / \mathrm{g}$ of Cha with cultivar $\mathrm{C}_{5}$ when treated by $\mathrm{K} 4$ of kinetin (Table 3). K3 of kinetin gave rise to the highest values (18.507 and $14.083 \mathrm{mg} / \mathrm{g}$ ) of $\mathrm{Chb}$ with cultivar $\mathrm{C}_{5}$ and $\mathrm{C}_{2}$, respectively. The highest value $(16.520 \mathrm{mg} / \mathrm{g})$ of Carot resulted of treatment of $\mathrm{K} 3$ kinetin with cultivar $\mathrm{C}_{5}$, followed by $13.523 \mathrm{mg} / \mathrm{g}$ of Carot which resulted of treatment of $\mathrm{K} 1$ kinetin with cultivar $\mathrm{C}_{2}$. On the other hand, $\mathrm{K} 2$ and $\mathrm{K} 4$ of kinetin led to the highest contents $(0.282$ and 0.277 $\mathrm{mg} / \mathrm{g}$ ) of Carb with cultivars $\mathrm{C}_{3}$ and $\mathrm{C}_{5}$, respectively (Table 3). Results pertaining to TP, TF, and TT indicate that treatment of $\mathrm{K} 3$ kinetin gave the highest contents $(13.633,15.147$, and $8.237 \mathrm{mg} / \mathrm{g}$ ) of TP, TF, and TT respectively with cultivar C5.

\section{Molecular characterization using ISSR markers}

The amplified fragments of DNA which generated monomorphic bands (MB), polymorphic bands (PB), primer sequences (PS), unique bands (UB), and the percentage of polymorphism $(P \%)$ in five Coleus cultivars are presented in Table 4 and Fig. 2.

A maximum of 39 DNA bands was scored in the ISSR profiles generated by primers 44B, HB-9, HB-12, HB-14, and HB-15. The size of the amplified bands ranged from about 260 to 1500 base pairs (bp); these bands were identified as 21 polymorphic bands (53.8\%) and 18 monomorphic ones. Eleven unique bands were identified in the resulted ISSR-profile generated by primers HB-9, HB-12, HB-14, and HB-15 (Table 4 and Fig. 2).

The primer 44B generated 2 monomorphic fragments with molecular sizes 365 and $415 \mathrm{bp}$. The fragments with molecular sizes $630 \mathrm{bp}$ and $920 \mathrm{bp}$ were scored with cultivars Solar red and finger paint, while the fragment with 
Table 1 Different cultivars affect the chemical analysis of Coleus blunei (mean of two seasons)

\begin{tabular}{llllllll}
\hline Cultivars & Cha $(\mathrm{mg} / \mathrm{g}, \mathrm{FW})$ & Chb $(\mathrm{mg} / \mathrm{g}, \mathrm{FW})$ & Carot $(\mathrm{mg} / \mathrm{g}, \mathrm{DW})$ & Carb $(\mathrm{mg} / \mathrm{g}, \mathrm{DW})$ & $\mathrm{TP}(\mathrm{mg} / \mathrm{g}, \mathrm{DW})$ & $\mathrm{TF}(\mathrm{mg} / \mathrm{g}, \mathrm{DW})$ & TT $(\mathrm{mg} / \mathrm{g}, \mathrm{DW})$ \\
\hline C1 & 1.535 & 5.910 & 5.494 & 0.238 & 6.039 & 6.871 & 3.446 \\
C2 & 2.914 & 8.398 & 9.838 & 0.212 & 7.108 & 11.814 & 4.069 \\
C3 & 1.209 & 3.654 & 3.733 & 0.224 & 7.769 & 6.926 & 4.501 \\
C4 & 1.401 & 5.458 & 4.901 & 0.222 & 7.908 & 8.648 & 4.871 \\
C5 & 2.763 & 12.013 & 10.594 & 0.266 & 10.853 & 11.648 & 6.722 \\
LSD = $\boldsymbol{P} \leq \mathbf{0 . 0 5}$ & 0.00519 & 0.00636 & 0.01288 & 0.00062 & 0.07252 & 0.22004 & 0.07884 \\
\hline
\end{tabular}

$C_{1}$ Color Clouds spicy, $C_{2}$ Beckwhites gem, $C_{3}$ Solar red, $C_{4}$ Colorblaze alligtore tears, $C_{5}$ finger paint, Cha chlorophyll a, Chb chlorophyll b, $C a r o t$ total carotenoids, Carb total carbohydrates, $T P$ total phenolic content, $T F$ total flavonoid content, $T$ total tannins content

molecular size 485 bp was absent in cultivars $C_{1}$ and $C_{4}$ only. Two monomorphic fragments with molecular sizes $600 \mathrm{bp}$ and $260 \mathrm{bp}$ were generated by primer HB-9. The fragment with molecular size $1335 \mathrm{bp}$, was exhibited in cultivars $C_{1}$ and $C_{3}$ only. Seven unique bands were identified; 3 of the positive markers with molecular sizes $930 \mathrm{bp}$, $570 \mathrm{bp}$, and $420 \mathrm{bp}$ had appeared with cultivar $\mathrm{C}_{4}$ only. While the 4 negative markers with molecular sizes $800 \mathrm{bp}$, $660 \mathrm{bp}, 500 \mathrm{bp}$, and $340 \mathrm{bp}$ were absent in cultivars $\mathrm{C}_{5}, \mathrm{C}_{1}$, $\mathrm{C}_{4}$, and cultivar $\mathrm{C}_{4}$ respectively. Two positive markers with molecular sizes $1060 \mathrm{bp}$ and $470 \mathrm{bp}$ were identified with cultivars $C_{2}$ and $C_{1}$ respectively having generated by primer HB-12. Four monomorphic fragments with molecular sizes 1430, 935, 680, and $370 \mathrm{bp}$ were recognized. The fragment with molecular size $820 \mathrm{bp}$ was exhibited in cultivars $C_{1}$ and $C_{2}$ only, while the fragment with molecular size $715 \mathrm{bp}$ appeared in cultivar $\mathrm{C}_{1}$ and cultivar $C_{3}$ only. The results of primer HB-14 showed that 4 monomorphic fragments with molecular sizes $1500 \mathrm{bp}, 1175 \mathrm{bp}$, $680 \mathrm{bp}$, and $620 \mathrm{bp}$ had exhibited. The fragment with molecular size $735 \mathrm{bp}$ was present in all cultivars except cultivar $\mathrm{C}_{4}$ only, so it is a negative marker. While the fragments with molecular sizes $500 \mathrm{bp}$ and $420 \mathrm{bp}$ were absent in cultivars $\mathrm{C}_{4}$ and $\mathrm{C}_{5}$ only, at the same time, the fragment was recognized at molecular size $380 \mathrm{bp}$ and was present in cultivar $\mathrm{C}_{4}$ and cultivar $\mathrm{C}_{5}$ only. One unique band was identified at about $1120 \mathrm{bp}$ with cultivar $\mathrm{C}_{2}$ having detected by primer HB-15. Seven monomorphic fragments were recognized with molecular sizes $1470 \mathrm{bp}, 970$ bp, 725 bp, 685 bp, 600 bp, 460 bp, and 375 bp
The results of ISSR analysis were pooled together to generate the dendrogram (Fig. 3). The five Coleus cultivars were divided into two main groups. The first comprises the four cultivars $C_{1}, C_{2}, C_{3}$, and cultivar $C_{5}$ which was subdivided into two subgroups; the first includes cultivars $C_{1}, C_{2}$, and cultivar $C_{3}$. The second subgroup had cultivar $\mathrm{C}_{5}$ only. The first subgroup was divided into two clusters; the first one includes cultivars $\mathrm{C}_{1}$ and cultivar $\mathrm{C}_{3}$ and the second cluster had cultivar $\mathrm{C}_{2}$ only. The second group includes the cultivar $\mathrm{C}_{4}$ only.

\section{Discussion}

Different five cultivars of Coleus revealed adequate amounts of pigments (chlorophyll a, chlorophyll b, and total carotenoids) as well as phytochemical ingredients including total carbohydrates, total phenolic, total flavonoids, and total tannins. These results are in accordance with the former results which discussed the chemical contents of different species of Coleus (Zhang et al. 2017). The present results indicated significant variations in the chemical contents of the studied five cultivars of Coleus treated by different concentrations of kinetin. The different treatments of kinetin presented general increase in pigment contents in the five studied cultivars of Coleus. These results are analogous with the results which indicated that kinetin application improved the contents of leaf chlorophyll and photosynthesis pigments in Vicia faba, maize, and tobacco (Ibrahim et al. 2007; Kaya et al. 2010; Rivero et al. 2010). Application of kinetin can increase the concentration of chlorophyll in the

Table 2 Different kinetin treatments affect the chemical analysis of Coleus blunei (mean of two seasons)

\begin{tabular}{llllllll}
\hline Treatment & Cha $(\mathrm{mg} / \mathrm{g}, \mathrm{FW})$ & Chb $(\mathrm{mg} / \mathrm{g}, \mathrm{FW})$ & Carot $(\mathrm{mg} / \mathrm{g}, \mathrm{DW})$ & Carb $(\mathrm{mg} / \mathrm{g}, \mathrm{DW})$ & $\mathrm{TP}(\mathrm{mg} / \mathrm{g}, \mathrm{DW})$ & $\mathrm{TF}(\mathrm{mg} / \mathrm{g}, \mathrm{DW})$ & TT $(\mathrm{mg} / \mathrm{g}, \mathrm{DW})$ \\
\hline K1 & 1.908 & 4.515 & 5.851 & 0.246 & 8.729 & 9.223 & 5.259 \\
K2 & 1.948 & 7.200 & 6.765 & 0.255 & 7.168 & 8.614 & 4.209 \\
K3 & 2.221 & 9.851 & 9.225 & 0.215 & 7.622 & 9.215 & 4.573 \\
K4 & 1.781 & 6.781 & 5.807 & 0.213 & 8.222 & 9.674 & 4.845 \\
LSD $=\boldsymbol{P} \leq \mathbf{0 . 0 5}$ & 0.00465 & 0.00569 & 0.01152 & 0.00056 & 0.06486 & 0.19681 & 0.07052
\end{tabular}

K1 0 ppm, K2 100 ppm, K3 150 ppm, K4 200 ppm, Cha chlorophyll a, Chb chlorophyll b, Carot total carotenoids, Carb total carbohydrates, TP total phenolic content, TF total flavonoid content, $\Pi T$ total tannins content 
Table 3 Interaction of different cultivars and kinetin treatments affects the chemical analysis of Coleus blunei (mean of two seasons)

\begin{tabular}{|c|c|c|c|c|c|c|c|}
\hline Interaction & Cha $(\mathrm{mg} / \mathrm{g}, \mathrm{FW})$ & $\mathrm{Chb}(\mathrm{mg} / \mathrm{g}, \mathrm{FW})$ & Carot (mg/g, DW) & Carb (mg/g, DW) & TP (mg/g, DW) & TF (mg/g, DW) & $\Pi \mathrm{T}(\mathrm{mg} / \mathrm{g}, \mathrm{DW})$ \\
\hline $\mathrm{C} 1+\mathrm{K} 1$ & 0.782 & 2.377 & 2.177 & 0.232 & 6.190 & 5.707 & 3.633 \\
\hline $\mathrm{C} 1+\mathrm{K} 2$ & 1.287 & 5.033 & 4.520 & 0.275 & 5.397 & 5.777 & 2.863 \\
\hline $\mathrm{C} 1+\mathrm{K} 3$ & 2.023 & 7.760 & 8.670 & 0.248 & 6.000 & 7.633 & 3.370 \\
\hline $\mathrm{C} 1+\mathrm{K} 4$ & 2.047 & 8.470 & 6.610 & 0.197 & 6.570 & 8.367 & 3.917 \\
\hline $\mathrm{C} 2+\mathrm{K} 1$ & 4.083 & 5.073 & 13.523 & 0.253 & 8.713 & 12.740 & 4.997 \\
\hline $\mathrm{C} 2+\mathrm{K} 2$ & 2.780 & 9.667 & 8.720 & 0.204 & 6.240 & 11.813 & 3.523 \\
\hline $\mathrm{C} 2+\mathrm{K} 3$ & 3.940 & 14.083 & 12.950 & 0.195 & 5.287 & 10.000 & 3.053 \\
\hline $\mathrm{C} 2+\mathrm{K} 4$ & 0.853 & 4.770 & 4.160 & 0.194 & 8.190 & 12.703 & 4.703 \\
\hline $\mathrm{C} 3+\mathrm{K} 1$ & 1.437 & 3.357 & 2.960 & 0.248 & 7.380 & 5.593 & 4.420 \\
\hline $\mathrm{C} 3+\mathrm{K} 2$ & 1.150 & 2.953 & 4.120 & 0.282 & 4.697 & 4.110 & 2.727 \\
\hline $\mathrm{C} 3+\mathrm{K} 3$ & 1.117 & 4.327 & 3.870 & 0.167 & 6.523 & 6.220 & 4.117 \\
\hline $\mathrm{C} 3+\mathrm{K} 4$ & 1.133 & 3.980 & 3.983 & 0.198 & 12.477 & 11.780 & 6.740 \\
\hline $\mathrm{C} 4+\mathrm{K} 1$ & 0.893 & 2.953 & 2.677 & 0.229 & 10.950 & 11.963 & 6.807 \\
\hline $\mathrm{C} 4+\mathrm{K} 2$ & 1.810 & 8.127 & 7.343 & 0.272 & 7.000 & 8.927 & 4.103 \\
\hline $\mathrm{C} 4+\mathrm{K} 3$ & 1.173 & 4.580 & 4.117 & 0.189 & 6.667 & 7.073 & 4.090 \\
\hline $\mathrm{C} 4+\mathrm{K} 4$ & 1.727 & 6.173 & 5.467 & 0.198 & 7.017 & 6.630 & 4.483 \\
\hline $\mathrm{C} 5+\mathrm{K} 1$ & 2.343 & 8.817 & 7.920 & 0.268 & 10.413 & 10.110 & 6.440 \\
\hline $\mathrm{C} 5+\mathrm{K} 2$ & 2.713 & 10.220 & 9.120 & 0.244 & 12.507 & 12.443 & 7.830 \\
\hline $\mathrm{C} 5+\mathrm{K} 3$ & 2.853 & 18.507 & 16.520 & 0.275 & 13.633 & 15.147 & 8.237 \\
\hline $\mathrm{C} 5+\mathrm{K} 4$ & 3.143 & 10.510 & 8.817 & 0.277 & 6.857 & 8.890 & 4.380 \\
\hline $\mathrm{LSD}=P \leq 0.05$ & 0.01039 & 0.01273 & 0.02576 & 0.00125 & 0.14495 & 0.43981 & 0.15681 \\
\hline
\end{tabular}

$C_{1}$ Color Clouds spicy, $C_{2}$ Beckwhites gem, $C_{3}$ Solar red, $C_{4}$ Colorblaze alligtore tears, $C_{5}$ finger paint, Cha chlorophyll a, Chb chlorophyll b, Carot total carotenoids, Carb total carbohydrates, TP total phenolic content, TF total flavonoid content, $T$ total tannins content, K1 0 ppm, K2 $100 \mathrm{ppm}, K 3150 \mathrm{ppm}, K 4200 \mathrm{ppm}$

plants through minimization of electrolytic leakage (Kaya et al. 2010), delaying chlorophyll decomposition by inhibition of chlorophyll activity, and through protection of chlorophyll photo-oxidation by increasing carotenoid concentration (Chernyad 2000). On the other hand, the decrease in chlorophyll and carotenoid content in some species of Coleus treated with some concentrations of kinetin might be owing to the degradation of these pigments or decrease in the efficiency of photosynthetic process which causes the low production of these pigments; this is in consensus with results which were

Table 4 Code and sequences of ISSR primers used in molecular characterization of identifying the five Coleus cultivars

\begin{tabular}{lllllll}
\hline PN & $\begin{array}{l}\text { PS } \\
5^{\prime} \rightarrow 3^{\prime}\end{array}$ & TB & MB & PB & UB & $P \%$ \\
\hline 44B & CTC TCT CTC TCT CTC TGC & 5 & 2 & 3 & - & 60 \\
HB-9 & GTG TGT GTG TGT GC & 10 & 2 & 8 & 7 & 80 \\
HB-12 & CAC CAC CAC GC & 8 & 4 & 4 & 2 & 50 \\
HB-14 & CTC CTC CTC GC & 8 & 4 & 4 & 1 & 50 \\
HB-15 & GTG GTG GTG GC & 8 & 7 & 1 & 1 & 12.5 \\
Total & & 39 & 18 & 21 & 11 & 53.84 \\
\hline
\end{tabular}

$P N$ primer name, $P S$ sequence, $T B$ total band, $M B$ monomorphic band, $P B$ polymorphic band, $U B$ unique band, $P \%$ polymorphism percentage reported earlier (Ouzounidou et al. 2010). The variation in the total carbohydrates in different cultivars of Coleus treated with different concentrations of kinetin in the present study might be accompanying with the effectiveness of photosynthetic process. These findings are in agreement with Singh and Prasad (2016); they reported that kinetin treatment increased the amounts of carbohydrate and chlorophyll. The results pertaining to the effects of kinetin treatments on contents of secondary metabolites (total phenolic, total flavonoids, and total tannins) in different cultivars of Coleus revealed dissimilarity in the effects of kinetin in Coleus cultivars. One hundred fifty parts per million and $200 \mathrm{ppm}$ of kinetin in this study stimulates secondary metabolites production in three cultivars of Coleus: Color Clouds spicy $\left(C_{1}\right)$, Solar red $\left(C_{3}\right)$, and finger paint cultivar $\left(C_{5}\right)$. These results are in accordance with Grzegorczyk-Karolak et al. (2017); they reported the similar stimulatory influence of cytokinins on biosynthesis process of flavonoid in Scutellaria alpina shoot cultures. This is analogous to the findings of Govindaraju et al. (2018) which indicated the effectiveness of cytokinin combined elicitor on enhancement of major secondary metabolite biosynthesis with stimulating phenylalanine ammonia lyase (PAL) gene expression in Coleus aromaticus Benth (L). The 

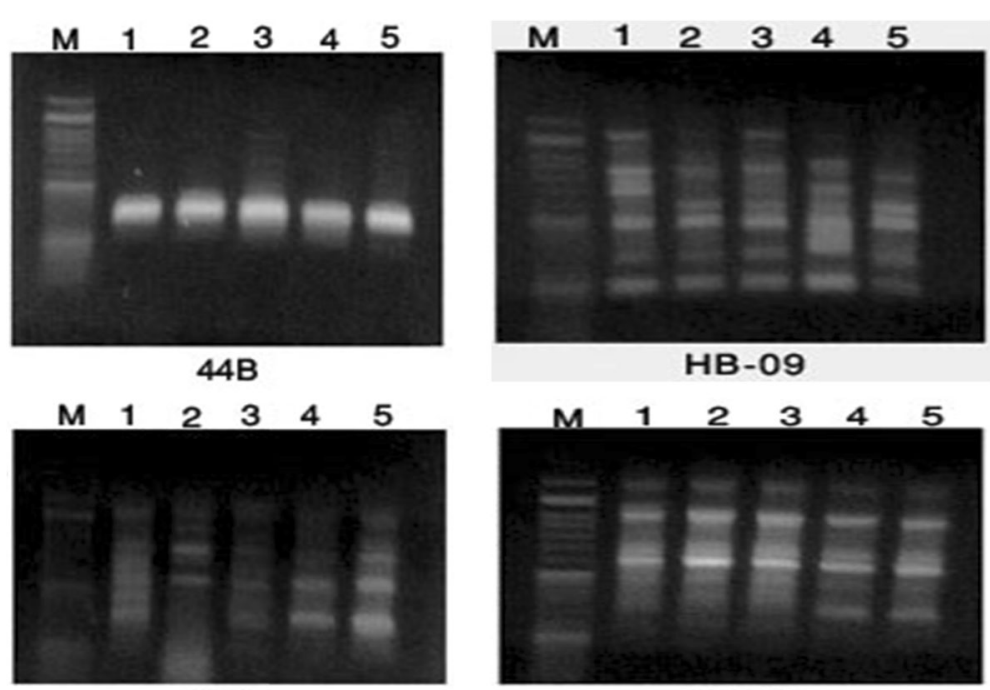

HB-12

HB-14

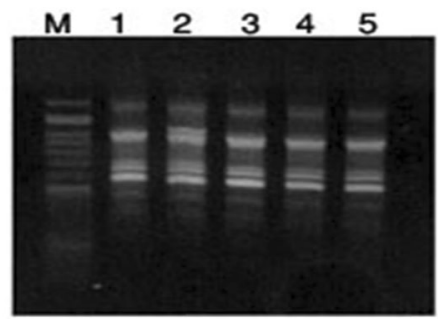

HB-15

Fig. 2 ISSR profile of five cultivars of Coleus generated by 5 primers, M, DNA Marker; 1, Color Clouds spicy, 2, Beckwhites gem; 3, solar red, 4, Colorblaze alligtore tears; 5 , finger paint

PAL stimulates the transformation of L-phenylalanine in phenylpropanoid pathway to trans-cinnamic acid which is the initiator of different polyphenolic compounds (Dixon and Paiva 1995). In this concern, Kostenyuk et al. (2002) stated that the phenolic production was improved because of overexpression of PAL in citrus transgenic roots. Consistently, Takshak and Agrawal (2018) reported that overexpression of cinnamyl alcohol dehydrogenase (CAD), PAL, dihydroflavonol reductase (DFR), 4-coumarate CoA ligase (4CL), and chalcone isomerase $(\mathrm{CHI})$ was associated with amelioration of the concentrations of flavonoids, tannins, anthocyanins, and lignin in Coleus forskohlii Briq. under ultraviolet-B radiation.
As for the ISSR analysis, similar results were obtained by many authors. Tripathi et al. (2013) used 10 ISSR primers to assess the morphological and molecular genetic diversity in 18 Coleus forskohlii cultivars, which produced 80 fragments and showed $68.75 \%$ polymorphism. Twelve germplasms from different populations were assessed for molecular fingerprinting by ISSR marker and densitometric quantification of forskolin in Coleus forskohlii Briq. A positive correlation between molecular and chemical fingerprints reflects the feasibility of the ISSR markers in analyzing genome information related to forskolin biosynthesis from varied phytogeography (Srivastava 2017). Liu et al. (2016) assessed 25 ISSR primers which were selected to amplify 95 Radix

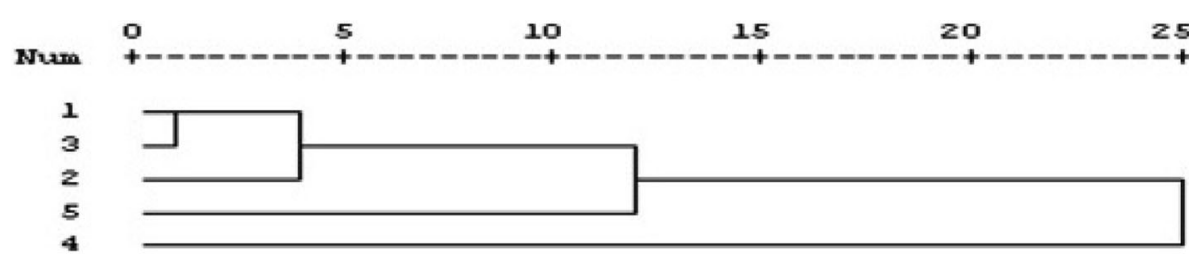

Fig. 3 Dendrogram illustrating genetic distance between the five cultivars of Coleus based on ISSR data 
Astragali. Jia et al. (2011) selected 10 ISSR primers to analyze the genetic diversity in pecan cultivars. Shafie et al. (2011) used ISSR markers for comparative analysis of genetic diversity in wormwood capillary (Artemisia capillaris). Twenty ISSR primers were tested for the amplification in Angelica sinensis (Oliv.) by Mei et al. (2015). The genetic diversity and phylogenetic analyses of seven species of Plectranthus (Lamiaceae) from Saudi Arabia were carried out by using 5 ISSR primers and generated 137 polymorphic amplified fragments, which pointed a relatively high level of genetic variation in Plectranthus (Abdel Khalik and Osman 2017).

\section{Conclusion}

The effects of kinetin treatments $(150 \mathrm{ppm}$ and 200 $\mathrm{ppm})$ stimulate secondary metabolite production in three cultivars of Coleus: Color Clouds spicy $\left(\mathrm{C}_{1}\right)$, Solar red $\left(C_{3}\right)$, and finger paint species $\left(C_{5}\right)$. ISSR analyses are important and are potent molecular tools for the study of genetic diversity and authentication of Coleus cultivars. Our study signifies the utility of metabolic and molecular fingerprints for identification of elite accessions and provides a lead to the industry for commercial exploitability of Coleus cultivars including its location in specific commercial cultivation.

\section{Abbreviations}

4CL: CoA ligase; bp: Base pairs; CAD: Cinnamyl alcohol dehydrogenase; Carb: Total carbohydrates; Carot: Total carotenoids; Cha: Chlorophyll a; Chb: Chlorophyll b; CHI: Chalcone isomerase; DFR: Dihydroflavonol reductase; ISSR: Inter-simple sequence repeats; MB: Monomorphic bands; P\%: Percentage of polymorphism; PAL: Phenylalanine ammonia lyase; PB: Polymorphic bands; PCR: Polymerase chain reaction; PS: Primer sequence; TB: Total bands; TF: Total flavonoids; TP: Total phenolic; TT: Total tannins; UB: Unique bands

\section{Acknowledgements}

The authors would like to thank the Genetics and Cytology Department, National Research Centre, Dokki, Egypt, Plant Biochemistry Department, National Research Centre, Dokki, Giza, Egypt, and Ornamental Plants and Woody Trees Dept., National Research Centre for their facilitation during this work.

\section{Authors' contributions}

The authors have participated and worked on completing this manuscript and approved the final manuscript.

\section{Funding}

The research was financed by the authors.

\section{Availability of data and materials}

All data generated or analyzed during this study are included in this manuscript.

\section{Ethics approval and consent to participate}

The manuscript does not contain studies involving human participants, human or animal data, and animal or human tissue.

\section{Consent for publication}

Not applicable.

\section{Competing interests}

The authors declare that they have no competing interests.

\section{Author details}

${ }^{1}$ Genetics and Cytology Department, National Research Centre, Dokki, GizaP.O. 12622Egypt. ${ }^{2}$ Plant Biochemistry Department, National Research Centre, Dokki, Giza, Egypt. ${ }^{3}$ Ornamental Plants and Woody Trees Dept., National Research Centre, Dokki, Egypt.

Received: 1 March 2020 Accepted: 8 June 2020

Published online: 26 June 2020

\section{References}

Abdel Khalik K, Osman G (2017) Genetic analysis of Plectranthus L. (Lamiaceae) in Saudi Arabia based on RAPD and ISSR markers. Pak. J. Bot 49(3):1073-1084 Adawy SS, Ebtisam A Hussein, Saker MM and Hanya A El-Itriby (2004) Intra and inter varietal variation of Upper Egypt date palm cultivars (Phoenix dactylifera L): 1. As revealed by RAPD and ISSR markers. Proceed Int. Conf. Genet. Eng. \& Appl..,m Sharm El-Sheikh, South Sinai, Egypt (April, 8-11,):165-179.

Chernyad EV (2000) Photosynthesis in sugar beet plants treated with benzyladenine and metribuzine during leaf development. Russ J Plant Physiol 42:183-189

Costa R, Graça P, Inmaculada G, Manuel MTS, Francisco E (2016) Comparison of RAPD, ISSR, and AFLP molecular markers to reveal and classify Orchardgrass (Dactylis glomerata L.) germplasm variations. https://doi.org/10.1371/journal. pone. 0152972

Dixon RA, Paiva NL (1995) Stress-induced phenylpropanoid metabolism. Plant Cell 7:1085-1097

Doyle JJ Doyle JL (1990). Isolation of plant DNA from fresh tissue focus 12:13-15

Govindaraju S, Arulselvi PI (2018) Effect of cytokinin combined elicitors (Iphenylalanine, salicylic acid and chitosan) on in vitro propagation, secondary metabolites and molecular characterization of medicinal herb Coleus aromaticus Benth (L). J Saudi Soc Agric Sci 17:435-444

Grzegorczyk KI, Rytczak P, Bielecki S, Wysokińska H (2017) The influence of liquid systems for shoot multiplication, secondary metabolite production and plant regeneration of Scutellaria alpina. Plant Cell Tissue Organ Cult 128(2):479-486

Hussein Ebtisam HA, Mohamed AA, Attia S, Adawy SS (2006) Molecular characterization and genetic relationships among cotton genotypes RAPD, ISSR and SSR analysis. Arab J Biotech 9:313-328

Ibrahim ME, Bekheta MA, El-Moursi A, Gaafar NA (2007) Improvement of growth and seed yield quality of Vicia faba L. plants as affected by application of some bioregulators. Australian J Basic App Sci 1(4):657-666

Jia XD, Tao W, Zhai M, Li YR, Guo ZR (2011) Genetic diversity and identification of Chinese-grown pecan using ISSR and SSR markers. Molecules 16:1007810092. https://doi.org/10.3390/molecules 161210078

Kaya C, Tuna AL, Okant AM (2010) Effect of foliar applied kinetin and indole acetic acid on maize plants grown under saline conditions. Turk J Agric For 34:529-538

Kostenyuk IA, Zon J, Burnsa JK (2002) Phenylalanine ammonia lyase gene expression during abscission in citrus. Physiol Planta 116:106-112

Li DY, Kang DH, Yin QQ, Sun XW, Liang LQ (2007) Microsatellite DNA marker analysis of genetic diversity in wild common carp (Cyprinus carpio L.) populations. J. Genet. Genom. 34(11):984-993

Liu Y, Pengfei Z, Ru Z, Meiling S, Fengbo L, Wenquan W, Junling H (2016) Analysis on genetic diversity of radix Astragali by ISSR markers. Adv Biosci Biotechnol 7:381-391

Mei Z, Chun Z, Khan M. A., Ye Z, Mousumi T, Peiyi L and Junjiang F (2015) Efficiency of improved RAPD and ISSR markers in assessing genetic diversity and relationships in Angelica sinensis (Oliv.) Diels varieties of China Electronic J. of Biotechnology 18 96-102

Mohamed AA, Ali SI, Sameeh MY, El-Razik TMA (2016) Effect of solvents extraction on HPLC profile of phenolic compounds, antioxidant and anticoagulant properties of Origanum vulgare. Res J Pharm Technol 9(11):2009

Ng WL, Tan SG (2015) Inter-simple sequence repeat (ISSR) markers: are we doing it right? ASM Sci I 9(1):30-39

Ouzounidou G, llias IF, Giannakoula A, Papadopoulou P (2010) Comparative study on the effects of various plant growth regulators on growth, quality and physiology of Capsicum annuum L. Pakistan J Botany 42:805-814

Polshettiwar SA, Ganjiwale RO, Wadher SJ, Yeole PG (2007) Spectrophotometric estimation of total tannins in some ayurvedic eye drops. Indian J Pharm Sci 69:574-576

Pospisilova J, Vagner M, Malbeck J, Travnickova A, Batkova P (2005) Interactions between abscisic acid and cytokinin during water stress and subsequent rehydration. Biologia Planta 49(4):533-540 
Rivero RM, Gimeno J, Deynze AV, Walia H, Blumwald E (2010) Enhanced cytokinin synthesis in tobacco plants expressing PSARK: IPT prevents the degradation of photosynthetic protein complexes during drought. Plant Cell Physiol 55(11):1929-1941

Sami AM, Shoaib RM, Ibrahim MM, Abo-Leila BH, Aboud KA, Mohamed SL (2018) Effect of kinetin on growth parameters and genetic diversity among some coleus cultivars by RAPD markers. Biosci Res 15(3):2558-2567

Saric MR, Kastrori CTC, Gerir I (1967) Vasiverzit et Novon Sadu. Praktikum Izfiziologize Biljaka- Beogard, Haucua Anjiga 215p.

Shafie MB, Sayed M, Zain H, Abdullah MZ, Ramisah MS (2011) RAPD and ISSR markers for comparative analysis of genetic diversity in wormwood capillary (Artemisia capillaris) from Negeri Sembilan, Malaysia. J Med Plants Res 5(18): 4426-4437

Shoaib RM, Abdel-Samea NS, Ramadan WA, Ibrahim MM, Aboud KA (2016) Elucidation of genetic parameters among some selected cultivars of prickly oil lettuce (lactucaserriolla L.) in Egypt, using morphoagronomic traits and RAPD markers. RJPBCS 7(3):1257-1264

Singh A, Prasad SM (2016) Kinetin ameliorates cadmium induced toxicity on growth, pigments and photosynthesis by regulating antioxidant potential in tomato seedlings. Int J Sci Eng Appl Sci 2(1):1-10

Singleton VL, Rossi JA (1965) Colorimetric of total phenolics with phosphomolibdicphosphor tungstic acid reagents. Am J Enol Vitic 16:144-158

Smith FM, Dubois M, Gilles KS, Hamilton DK, Rebers PA (1956) Colormetric methods for determination of sugars and related substances. Annal chem 28 350-356

Snedecor GW, Cochran WG (1980) Statistical methods, 7th ed. lowa state Univ., press Aner. lowa, USA.

Srivastava S, Ankita M, Priyanka M, Pushpendra S, Manish K, Velusamay S, Kuldeep SN, Pawan KA, Ajay KSR (2017) Molecular and chemotypic variability of forskolin in Coleus forskohlii Briq., a high value industrial crop collected from Western Himalayas (India) RSC Adv., 7, 8843-8851.

Steel RGD, Torrie JH (1980) Principles and procedures of statistics. A biometrical approach, 2nd edn. M.C. Graw-Hill Book Co., New York, p 688

Takshak S and Agrawal SB (2018) Interactive effects of supplemental ultraviolet-B radiation and indole-3-acetic acid on Coleus forskohlii Briq.: alterations in morphological-, physiological- and biochemical characteristics and essential oil content. Ecotoxicology and environmental safety, Jan 31;147:313-26.

Tripathi N, Navinder S, Sharad T (2013) Morphological and molecular characterization of endangered medicinal plant species Coleus forskohlii collected from Central India. J Crop Sci Biotech 16(4):253-261. https://doi. org/10.1007/s12892-013-0083-9

Yang X, Quiros CF (1993) Identification and classification of celery cultivars with RAPD markers. Theorit Appl Genetics 86:205-212

Zhang L, Jia LL, Sui JX, Wen MX, Chen YJ (2017) Ameliorating effects of three kinds of antioxidants to ozone-polluted painted nettle (Coleus blumei Benth.). Photosynthetica: $1-10$

Zhishen J, Mengcheng T, Jianming W (1999) The determination of flavonoid contents in mulberry and their scavenging effects on superoxide radicals. Food Chem 64:555-559

\section{Publisher's Note}

Springer Nature remains neutral with regard to jurisdictional claims in published maps and institutional affiliations.

\section{Submit your manuscript to a SpringerOpen ${ }^{\circ}$ journal and benefit from:}

- Convenient online submission

- Rigorous peer review

- Open access: articles freely available online

- High visibility within the field

- Retaining the copyright to your article

Submit your next manuscript at $\boldsymbol{\nabla}$ springeropen.com 